\title{
Changes in Operating Practice for Increasing the Life of Pots in ALRO SLATINA
}

\author{
Gheorghe Dobra, \\ Marin Cilianu and Gilbert Ciobanu* \\ VIMETCO ALRO \\ 116 Pitesti Str., Slatina, 230048, Romania
}

Changes in operating practice has made ALRO one of the most efficient smelters of its generation in the world. Aiming to design a high performance pot technology, with high productivity and low capital expenditures, ALRO has redesigned its low-amperage pots in order to create an advanced pot, by integrating the latest technology in lining design and anode rodding, in such a way as to maximize pot production by amperage increase, without decreasing the technical performance and potlife; we were thus able to obtain increase of the potlife from 1,440 days in 2004 to 2,860 days in 2016 and decrease of the DC reactive power consumption, from $14.18 \mathrm{MWh} / \mathrm{Mt}$ to 13.28 MWh/Mt.

Keywords: low-amperage pot, potlife, ALRO'S ELECTROLYSIS POT, failure mode, pot design.

\section{Изменения в производственной деятельности, направленные на повышение срока службы электролизеров на заводе ALRO SLATINA}

\author{
Георге Добра, Марин Чилиану, Гилберт Чобану \\ VIMETCO ALRO \\ Румыния, 230048, Слатина, ул. Pitesti, 116
}

Изменения в производственной деятельности сделали ALRO одним из наиболее эффективных заводов своего поколения в мире. Стремясь разработать высокоэффективную технологию электролизера с высокой производительностью и малыми капитальными затратами, ALRO переконструировал их низкоамперные ванны, чтобы создать усовершенствованный электролизер, внедрив последние разработки конструкиии футеровки и монтажа анодов,

(C) Siberian Federal University. All rights reserved

* Corresponding author E-mail address: dobra@alro.ro, mcilianu@alro.ro,gciobanu@alro.ro

$$
-387-
$$


чтобы таким образом максимально повысить производительность ванны за счет повышения силь тока, без снижения технических характеристик и срока службы. В результате мы смогли получить увеличение срока службы с 1440 дней в 2004 г. до 2860 дней в 2016 г. и снижение расхода реактивной мощности постоянного тока с 14,18 до 13,28 MBтч/Mm.

Ключевые слова: высокоамперный электролизер, срок службы, конструкция электролизера, режим отказа, электролизер ALRO.

\section{History of Alro}

Established in 1965 based on Pechiney technology, Alro started its venture with two potrooms producing 50,000 tons per year. Production capacity increased with the addition of new potrooms and as a result, during the ' 80 s, the company reached its maximum capacity of 263,500 tons. At the time, Alro had in operation 4 potrooms with 176 pots each of $65 \mathrm{kA}$ and 6 potrooms with 128 pots each of $83 \mathrm{kA}$, side by side, 16 anodes, end riser, side worked prebaked pots.

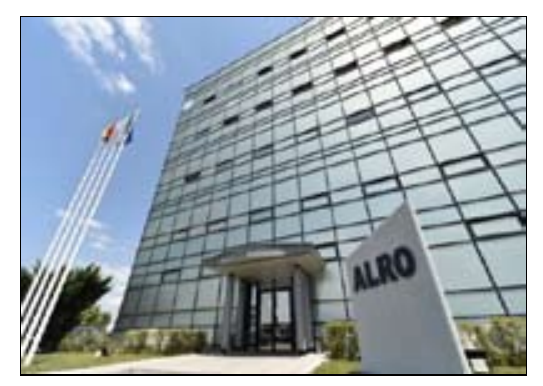

During the period 1990-1991, following the 1989 Romanian revolution, a change in national priorities, shortage of power and low metal prices led to a capacity reduction to 110,000 tons/year. Part of the shutdown capacity was reinstated during 1994 and in 1995 the Alro management decided to modernize all six higher amperage potrooms by converting the pots to computer controlled point feeding, hooding and dry scrubbing. The retrofitting process was completed in the second half of 2002 when the last two potrooms were converted and second dry scrubbing unit was commissioned.

On April 30, 2002 Alro became a private company as Vimetco (former Marco International) purchased the main stock of shares. With the help of a consultant team it was decided that, by certain design changes, Alro pot would be able to perform at much higher amperage, namely $120 \mathrm{kA}$, compared to the original level of $83 \mathrm{kA}$, offering Alro an output of 265,000 tons/year electrolytic aluminium, the same value achieved when all 10 potrooms were in operation.

During 2008-2011, due to the unfavourable market conditions, ALRO was forced to shutdown 2 potrooms (Potrooms no. 9 and no. 10); Potroom no. 9 was afterwards restarted in 2011, most of the pots being started-up with recovered cathode (Fig. 1).

At present, ALRO is a private-owned company, the largest primary aluminum smelter in Eastern Europe. Its product range includes billets, slabs, wire rod, plates, sheets and strips.

\section{Increasing potlife}

Increasing the life of pots was a continuous long-term process. The processes consisted of the following: 


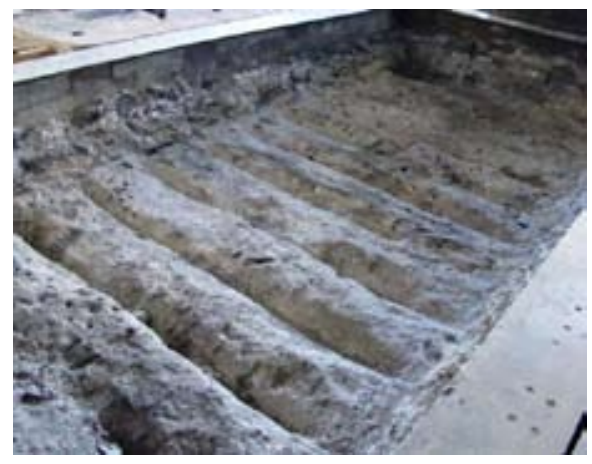

Fig. 1. Electrolysis pot with recovered cathode

- Test and use the most efficient pot construction materials;

- Improve the execution of pot repair works;

- Improve pot heating process for start-up purposes;

- Improve the procedure of "no anode effect" pot start-up;

- Promote best practices for strict control of pot temperature until the metal inventory is added to the pot;

- Strict observance and additional control of the pot thermal condition during the first months of operation;

- Correlate pot age with pot metal level;

- Strict control of pot temperature during its entire operating life;

- Implement necessary measures to reduce the number of anode effects to $0.02 \mathrm{EA} /$ pot*day; $^{*}$

- Improve the pot heat insulation procedure (including the use of an optimum anode cover mixture);

- A pot materials database was also implemented (this facilitated evaluation of different materials used to reline the pots);

- Establish responsibility of operators by organizing works in such a matter that each operator should be responsible for the performances of the pots where such operator performs all basic works (anode change, heat insulation etc);

- Periodic operator training and promotion of best practices.

Implementation of the above measures during 2004 - 2016 led to the increase of potlife from 1440 days to 2860 days, as shown in Fig. 2.

The average life of pots stopped in 2011 is influenced by the average lifespan of pots in operation from Potroom no. 10, which was shutdown in 2011 for economic reasons.

In year 2016 the decrease of the average lifespan is mainly due to the shutdown of some pots in Potroom no. 9 which had been started-up with the recovered cathodes.

\section{Description of Alro's electrolysis pot}

Fig. 3 below presents a simplified drawing of an electrolysis pot. Starting from the old pot design a modified design was developed to support the altered heat balance in order to replace the pots that failed before being able to test and establish the best design in the test section.

$$
-389-
$$




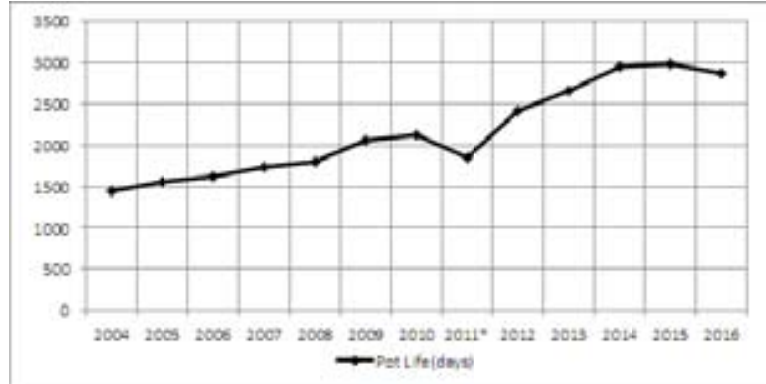

Fig. 2. Pot Life evolution

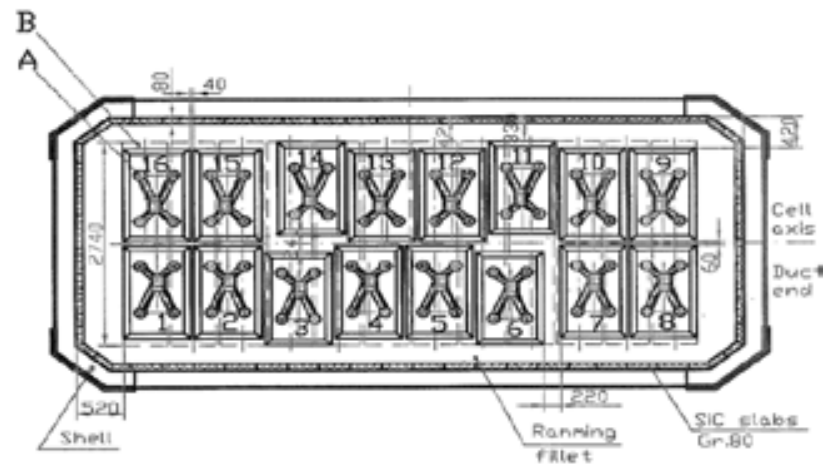

Fig. 3. Electrolysis pot simplified drawing: A: rodded anodes: 1250 x 750 x $620 \mathrm{~mm}$; B: cathode blocks: $2740 \times 500 \times 450 \mathrm{~mm}$

Modifications applied consisted of:

- increased cathode block length from 2400 to $2740 \mathrm{~mm}$, in order to keep the same cathode current distribution;

- graphite content in cathode was increased to $30 \%$;

- decreased thickness of the sidewall in order to accommodate the longer cathode block;

- dimensions of the cathode bar were altered to be able to eliminate more heat through the cathode bar, to improve the contact between the bar and the block and to optimize cathode current distribution;

- shape of the cathode blocks center channel was also altered;

- shell plate thickness was doubled;

- a removable deckplate was applied in the top of the shell and the beams were reinforced in order to increase the shell resistance and minimize the shell bowing.

\section{Experimental procedure}

Autopsies were performed on several test pots in order to examine condition of the cathodes at $120 \mathrm{kA}$ and the impact of electrolyte penetration to the bottom. Integrity of the cathode blocks in this condition was carefully evaluated and determined changes in construction practices and carefully selection of materials for pot construction. 
The autopsies are conducted on pots on the production site, in the potroom. The entire bath and metal are removed to make possible to observe and measure the cathode blocks' and sidewalls' surface. After that, if necessary, one or more cathode blocks together with bricks beneath them are removed, thus exposing cross sections for every pot. The cross sections are studied, drawn and pictures are taken.

\section{Goal and objectives \\ of cathode block assembly design evaluation at Alro's pots}

Determine the reference conditions found at ALRO's pots in order to compare them with the ones of the test pots and existing pots as the amperage is increased.

The main part of this activity consisted in full autopsy of several electrolysis pots, in various stages of power amperage increase.

In any pot autopsy, the objectives consist in evaluating the pot with regard to:

1. failure mode (in some cases the autopsies are conducted on non-failed pots), including identification of any possible mode of failure;

2. complete thermal balance, which depends on cathode system design and pot performance history.

This comprises three parts:

a) conservation of original insulating layer;

b) proper location of bath solidification-melting isotherm;

c) sidewall protection by slope.

3. quality and performance of materials used for pot construction;

4. operations for pot construction, such as ramming, bricks setting etc.

In conclusion, the autopsy of an electrolysis pot highlights:

- correlation between the quality of materials used in construction and the pot's operating parameters, which validate or not their quality;

- quality of operations during pot operation, validating or not the procedures of heating, start-up and further operation.

From this point forward, the statiscs and interpretation given by database analysis show good prediction of pot lifespan using Weibul methods.

\section{Failure mode}

ALRO's Potrooms were part of an upgrading program in a contract with Aluminium Pechiney, which also included pot hooding, central feeding, process flow automation and waste gas scrubbing.

Once the conversion to central feeding was finalized, the main mode of pot failure changed from failure on pot bottom to sidewall failure. Chart of failures distribution is shown in Fig. 4 below.

This type of failure (sidewall failure) would further be prevalent during the power amperage increase. Measurements of sidewall erosion in $\mathrm{SiC}$ slabs pots during autopsy coincides with statistical data, which indicated a higher failure, rate at the offset anodes 3 and 11.

As a result of failure investigations, certain modifications were made as follows:

- depending on cathode type and length, metal height was increased in order to release more heat through the sidewall; 


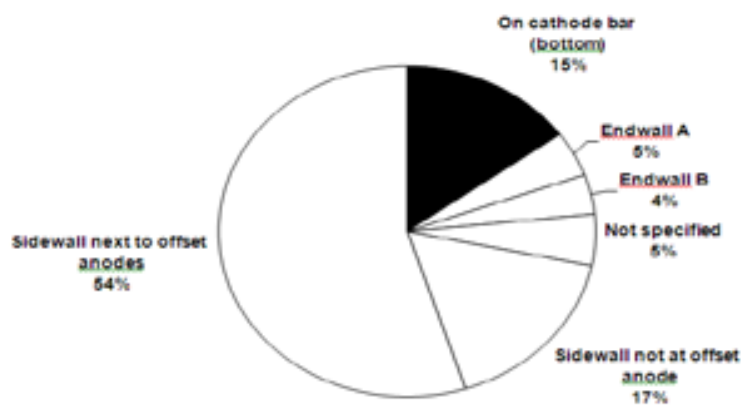

Fig. 4. Failure distribution at ALRO's pots with central feeding

- old ramming procedure based on number of strokes and time measurement was replaced by a new ramming procedure based on layer compaction ratio measurement;

- heat up procedure was adjusted. Number of shunts used during the heat up was increased from 2 to 3 and to protect the ramming fillet; we started using a sandwich type material consisting of cryolite, coarse crust and fine bath;

- tapping schedule was modified from 48 to 32 hours;

- bath level was increased from $17 \mathrm{~cm}$ to $19 \mathrm{~cm}$ in order to keep the same bath volume;

- start up procedure was adjusted and the occurrence of the anode effect was eliminated.

\section{2.a. Preservation of the original insulating layer}

The refractory materials on the bottom and the insulating structure are built directly on a concrete flooring, which does not allow for air circulation under it.

At the performed autopsies it was found that the five layers of bricks ware irreversibly damaged because of the bath penetration and formation of a refractory materials and bath monolith. Formation of the refractory materials and bath monolith is related to the pot design that places the insulating layers directly on the floor, acting like an infinite heat absorbing medium. The bricks on the bottom area of the wall are less penetrated by bath indicating the fact that this area is colder compared to the bottom from the center of the pot.

\section{2.b. Appropriate location of the bath solidification-melting isotherm}

At the performed autopsies it was found that the bath solidification-melting isotherm was located outside the cathode block, deeply inside the refractory layers.

\section{2.c. Sidewall protection through a slope}

The performed slope measurements showed that, although the fillet was slightly eroded at the metalbath interface, an adequate slope was created on the surface of the fillet and of the silicon carbide slabs.

\section{Quality and performance of the materials used for pot construction}

\section{Cathode blocks}

The performed autopsies revealed that the cathode blocks produced in Romania, which consisted of $80 \%$ gas calcined anthracite and $20 \%$ graphite (GCA type), were prone to horizontal 
cracking, as shown by Fig. 5, and would not withstand the $120 \mathrm{kA}$ amperage. The purpose on the long term was for Alro to use high quality cathodes that were fully qualified in compliance with the aluminium industry standards. First step of the qualification process was to send the samples taken from the domestic cathode blocks to be analyzed by an international certified laboratory and to compare the results with the results achieved for other types of blocks from other producers.

Two cathode samples were analyzed (taken perpendicularly on the forming direction of the cathode blocks) for petroghaphycal analysis and the results are presented in the Table 1.

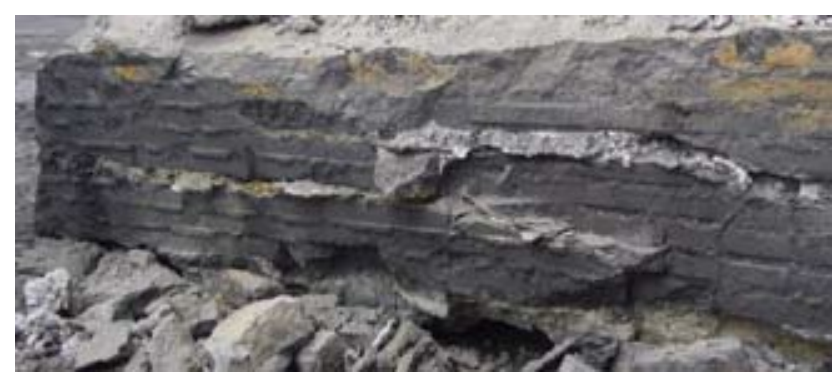

Fig. 5. Metal infiltrations in the horizontal cracks of a domestic cathode

Table 1. Petrographycal composition analysis of the domestic cathode samples

\begin{tabular}{|c|c|c|}
\hline Cathode no. & 224-02 & 224-08 \\
\hline Anthracite & $\%$, of the volume & $\%$, of the volume \\
\hline$+300 \mu \mathrm{m}$ & 35.2 & 29.5 \\
\hline $300-100 \mu \mathrm{m}$ & 7.5 & 4.0 \\
\hline $100-10 \mu \mathrm{m}$ & 6.2 & 8.4 \\
\hline total & 48.9 & 41.9 \\
\hline \multicolumn{3}{|l|}{ Petroleum coke } \\
\hline$+300 \mu \mathrm{m}$ & 0 & 0.1 \\
\hline $300-100 \mu \mathrm{m}$ & 2.3 & 4.3 \\
\hline $100-10 \mu \mathrm{m}$ & 10.7 & 16.1 \\
\hline total & 13.0 & 20.5 \\
\hline $\begin{array}{l}\text { Binding material phase (anthracite and petroleum } \\
\text { coke, fine size grain }<10 \mu \mathrm{m} \text {, mixed with pitch coke) }\end{array}$ & 22.2 & 19.7 \\
\hline \multicolumn{3}{|l|}{ Soft Graphite Material } \\
\hline$+300 \mu \mathrm{m}$ & 0.1 & 2.5 \\
\hline $300-100 \mu \mathrm{m}$ & 0.9 & 0.7 \\
\hline $100-10 \mu \mathrm{m}$ & 4.9 & 2.3 \\
\hline total & 5.9 & 5.5 \\
\hline Pores & 9.1 & 11.2 \\
\hline Minerals & 0.9 & 1.2 \\
\hline TOTAL & 100 & 100 \\
\hline Medium-max. oil reflexion, (25 points) & $10.83 \%$ & $9.52 \%$ \\
\hline
\end{tabular}




\section{Results interpretation}

a. The petrographycal analysis revealed different types of anthracite in each sample, as it was expected, because sample \# 224-02 was a GCA type and sample \# 224-08 was a ECA type.

b. The presence of the plumbaginous petroleum coke was revealed as partial replacement for the electrographite. The usage of the plumbaginous petroleum coke increases the cathode blocks destructive process in the electrolysis pots. Both cathode samples had a significant percentage of plumbaginous petroleum coke.

c. The ECA and GCA type samples were similar, especially in terms of density, thermal conductivity, ash content, compression resistance.

d. The values of the expansion to sodium attack in certain domestic cathodes samples were higher than the values obtained when testing blocks of other producer, performed in the same laboratory.

e. The domestic blocks had one of the highest resistivities ever measured by the laboratory where they were tested.

f. Other properties ranged within the normal values.

\section{Actions taken}

The cathode blocks technical specification was revised in terms of values and the mechanicalchemical properties.

Import blocks were tested and qualified.

The domestic cathode blocks have no longer been used, instead imported cathode blocks have been used during the amperage increase period and at present.

\section{Ramming paste}

The performed autopsies revealed that the hot ramming paste produced in ALRO was prone to cracking and therefore to metal and electrolyte infiltrations.

Four samples of hot ramming paste were tested in an international certified laboratory and the results are presented in Table 2 .

\section{Results interpretation}

a. Expansion to sodium attack: The values of ALRO hot paste containing plumbaginous coke were high, and conclusively, this kind of paste was not viable. The values should have been less than $1.0 \%$, as the lowest possible level.

b. The low ash level showed that the anthracite or graphite replaced to a certain extent other carbon materials, but the paste also contained petroleum coke or metallurgical coke, taking into account the high values obtained for the expansion to sodium attack.

c. Other properties ranged within the normal values.

\section{Actions taken}

The technical specification for the cold ramming paste applied at ambient temperature was drafted.

Different types of imported cold ramming paste were tested and qualified.

$$
-394-
$$


Table 2. Laboratory results achieved for Alro hot ramming paste

\begin{tabular}{|c|c|c|c|c|}
\hline Sample no. & $\begin{array}{c}03-262 \\
01 A\end{array}$ & $\begin{array}{c}\text { 03-262 } \\
01 B\end{array}$ & $\begin{array}{c}\text { 03-262 } \\
02 A\end{array}$ & $\begin{array}{c}03-262 \\
02 A\end{array}$ \\
\hline Green paste density, $\mathrm{g} / \mathrm{cm} 3$ & 1.540 & 1.554 & 1.563 & 1.587 \\
\hline Dried green paste density, $\mathrm{g} / \mathrm{cm} 3$ & 1.296 & 1.308 & 1.316 & 1.336 \\
\hline Weight loss, $\%$ & 4.3 & 4.2 & 4.5 & 4.4 \\
\hline Medium dimensional change, $\%$ & -0.95 & -0.59 & -0.72 & -0.34 \\
\hline Volume change, $\%$ & -2.82 & -1.76 & -2.15 & -1.02 \\
\hline Coking value in the pot, $\%$ & 72.8 & 73.3 & 71.8 & 72.2 \\
\hline Baked paste density, g/cm3 & 1.516 & 1.515 & 1.526 & 1.533 \\
\hline Electrical resistivity, $\mu \Omega \mathrm{m}$ & 63.5 & 64.1 & 56.2 & 58.6 \\
\hline Air permeability, $\mathrm{nPm}$ & 4.49 & 3.21 & 3.73 & 3.27 \\
\hline Ash content, $\%$ & 3.14 & 3.14 & 3.17 & 3.18 \\
\hline \multicolumn{5}{|l|}{ Metals, \%: } \\
\hline $\mathrm{Ca}$ & 0.154 & 0.154 & 0.154 & 0.154 \\
\hline $\mathrm{Fe}$ & 0.436 & 0.431 & 0.451 & 0.448 \\
\hline $\mathrm{Na}$ & 0.039 & 0.038 & 0.037 & 0.037 \\
\hline $\mathrm{Ni}$ & 0.004 & 0.006 & 0.004 & 0.004 \\
\hline $\mathrm{S}$ & 0.53 & 0.51 & 0.50 & 0.51 \\
\hline $\mathrm{Si}$ & 0.536 & 0.569 & 0.518 & 0.534 \\
\hline $\mathrm{V}$ & 0.006 & 0.006 & 0.006 & 0.006 \\
\hline Real density, g/cm3-He & 1.987 & & 1.997 & \\
\hline Thermal conductivity, $\mathrm{W} / \mathrm{mK}$ & 2.85 & 3.20 & 3.54 & 3.24 \\
\hline Thermal dilatation coefficient, $\mathrm{ppm} /{ }^{\circ} \mathrm{C}$ & 4.97 & 5.15 & 5.09 & 5.11 \\
\hline Cold compression resistance, $\mathrm{kg} / \mathrm{cm} 2$ & 131 & 155 & 203 & 218 \\
\hline Young module, N/m2 x 108 & 10.8 & 14.9 & 18.6 & 21.0 \\
\hline Bending resistance, $\mathrm{kg} / \mathrm{cm} 2$ & 27 & 39 & 51 & 38 \\
\hline Expansion at sodium, \% & 2.20 & 1.86 & 1.21 & 1.57 \\
\hline Absorption of sodium, $\mathrm{g} / \mathrm{cm} 3$ & 0.47 & 0.44 & 0.46 & 0.44 \\
\hline
\end{tabular}

The hot ramming paste produced in ALRO has no longer been used, instead imported cold ramming paste has been used during the amperage increase period and at present.

\section{Nitrided silicon carbide slabs}

The nitrided silicon carbide slab $\left(\mathrm{Si}_{3} \mathrm{~N}_{4}-\mathrm{SiC}\right)$ used and recovered from a shutdown electrolysis pot was analyzed in terms of:

- description of the general appearance and of the cross section;

- mineral composition in different positions;

- microstructure analysis by SEM and elements composition by EDAX.

The recovered silicon carbide slab is shown in Fig. 6. The darker area with electrolyte deposit represents the inner work side and the opposite side slightly covered by grout represents the shell side. 


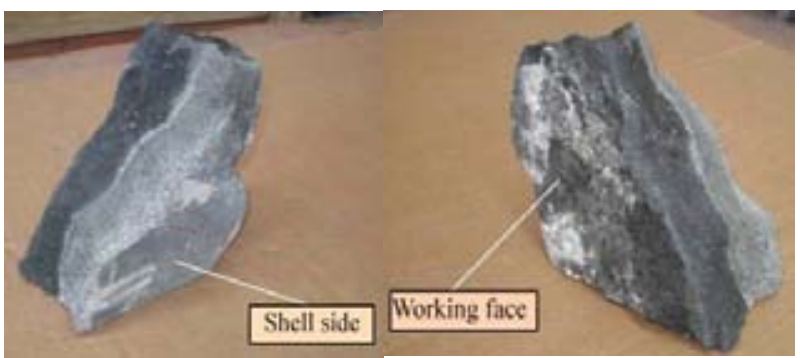

a) shell view; $\quad$ b) work side view

Fig. 6. Appearance of the sample

\section{Description of the cross section}

The sample was split into 5 layers, as seen in Fig. 7, starting from the inner work side towards the outer shell side.

1. Black - pitch colour layer: section up to $20 \mathrm{~mm}$ from the work side;

2. Brilliant black colour layer: section between $20-40 \mathrm{~mm}$ from the work side;

3. Transition layer: section between $40-50 \mathrm{~mm}$ from the work side. This section appeared to be white and thin, connecting the inner black layers to the outer layers;

4. Loose layer: section between $50-65 \mathrm{~mm}$ from the work side. This section was loose and could be crushed by hand;

5. Original layer: section from $65 \mathrm{~mm}$ at the outer side, namely the area of up to $15 \mathrm{~mm}$ from the outer side. Visually, it generally continued to have the original shape/appearance.

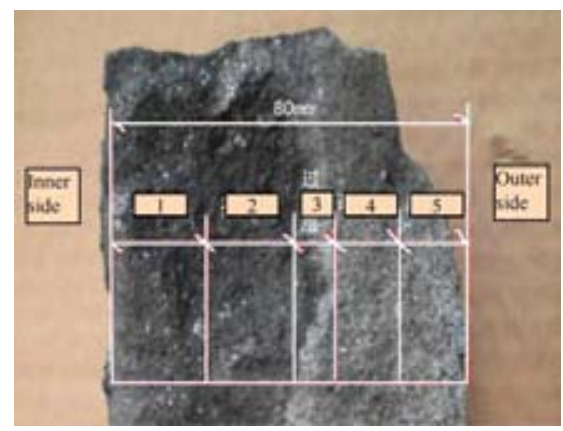

Fig. 7. Layer delimitation

\section{XRD Analysis}

XRD test was made on the specimens taken from each layer and from the electrolyte deposited on the work side.

The results are indicated in Fig. 8 which shows that $\mathrm{SiC}$ remains the main phase.

The XRD quantitative analysis is shown in Table 3 below.

As shown by the XRD analysis result, $\alpha-\mathrm{Si}_{3} \mathrm{~N}_{4}$ exists in the slab only in the pitch black layer and in the original layer, and its content is lower in the pitch black layer than it is in the original layer. 


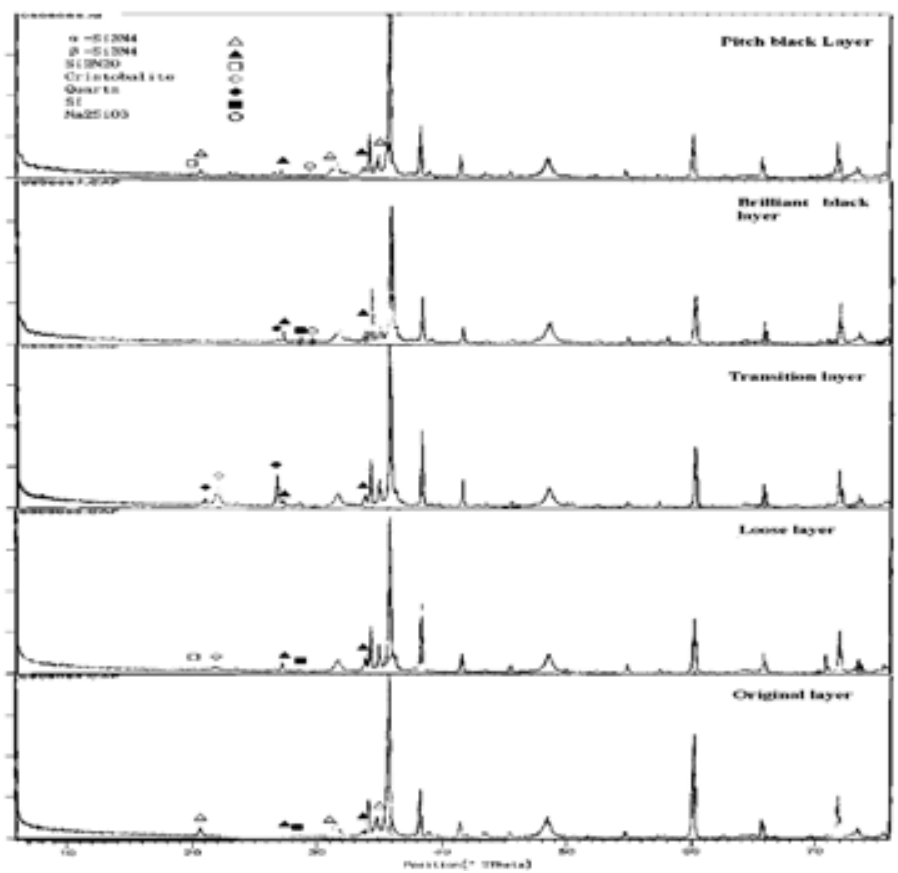

Fig. 8. XRD Spectrum of the 5 layers

Table 3. XRD analysis results, $\%$

\begin{tabular}{|l|c|c|c|c|c|c|c|}
\hline \multicolumn{1}{|c|}{ Item } & $\alpha-\mathrm{Si}_{3} \mathrm{~N}_{4}$ & $\beta-\mathrm{Si}_{3} \mathrm{~N}_{4}$ & $\mathrm{Si}$ & Cristobalite & Quartz & $\mathrm{Si}_{2} \mathrm{~N}_{2} \mathrm{O}$ & $\mathrm{Na}_{2} \mathrm{SiO}_{3}$ \\
\hline Black - pitch layer & 6 & 4 & - & - & - & $<1$ & $1-3$ \\
\hline Brilliant black layer & - & 9 & 1 & - & $<1$ & - & 3 \\
\hline Transition layer & - & 7 & - & $3-5$ & 5 & - & - \\
\hline Loose layer & - & 10 & $<1$ & 3 & & $<3$ & - \\
\hline Original layer & 14 & $1-3$ & $<0.5$ & - & - & - & - \\
\hline
\end{tabular}

During the operation, $\mathrm{SiC}$ slab in the pot is exposed to an oxidising environment $\left(\mathrm{CO}, \mathrm{CO}_{2}, \mathrm{O}_{2}\right)$. Normally, the resistance of $\mathrm{Si}_{3} \mathrm{~N}_{4}$ to oxidation is lower than the resistance of $\mathrm{SiC}$, and the resistance of $\alpha-\mathrm{Si}_{3} \mathrm{~N}_{4}$ is lower than that of $\beta-\mathrm{Si}_{3} \mathrm{~N}_{4}$. Thus, except for the pitch-black layer and the original layer, the $\alpha-\mathrm{Si}_{3} \mathrm{~N}_{4}$ in the other layers has already oxidised. Since $\beta-\mathrm{Si}_{3} \mathrm{~N}_{4}$ shows a better oxidation resistance capacity as compared to $\alpha-\mathrm{Si}_{3} \mathrm{~N}_{4}$, it can be detected in all the layers.

\section{Results interpretation}

a. The nitrided $\mathrm{SiC}$ slabs showed no quality problems considering that the results of the XRD and SEM analysis for the slab side towards the shell were almost the same with those of the original slab.

b. The consumed slab forms flakes from the work side (coming in contact with the bath) towards the shell side and the XRD, SEM and EDAX results of different layers differentiated distinctly one from the other. 


\section{Actions taken}

The nitrided SiC slabs continue to be used for the electrolysis pots relining in ALRO.

\section{Refractory bricks}

The purpose was to assess, using the CUP test, the resistance of the domestic refractory bricks to bath attack as it takes place in the electrolysis pots.

Table 4 presents the results achieved in the laboratory tests.

\section{Results interpretation}

a. The bricks delivered by producer $\# 2$ had the most unsatisfactory performance of all the tests ever performed. All three bricks failed and the bath came out of the open pores almost immediately after melting.

b. The bricks from producer \#1 also had a poor performance, however, two of the three bricks held the molten bath sufficiently so that the corrosion test could be completed.

c. the weak resistance to bath etching was the cause concurring to the formation of molten refractory material and bath monolith in Alro pots. The impact of the monolith formation over the pot lifetime is still unclear (our pot are still placed on the ground).

\section{Actions taken}

The technical specification for the refractory bricks was revised in terms of values and mechanicalchemical properties. Refractory bricks from other Romanian producers and external producers were also tested and qualified.

Table 4. Laboratory analysis results for refractory bricks delivered by 2 Romanian producers

\begin{tabular}{|l|c|c|c|c|c|c|c|c|}
\hline Description & \multicolumn{3}{|c|}{ Domestic producer 1 } & \multicolumn{3}{c|}{ Domestic producer 2 } \\
\hline Samples & $\mathbf{1}$ & $\mathbf{2}$ & $\mathbf{3}$ & Average & $\mathbf{1}$ & $\mathbf{2}$ & $\mathbf{3}$ & Average \\
\hline Original hole dimensions & & & & & & & & \\
\hline - Height, cm & 8.831 & 8.959 & 8.832 & & 8.834 & 8.854 & 8.864 & \\
\hline - Diameter, cm & 2.668 & 2.661 & 2.655 & & 2.665 & 2.665 & 2.627 & \\
\hline - Area, cm ${ }^{2}$ & 23.56 & 23.84 & 23.46 & & 23.43 & 23.60 & 23.29 & \\
\hline Bath weight, g & 91.0 & 89.5 & 87.3 & & 87.3 & 85.7 & 85.5 & \\
\hline Final hole dimensions & & & & & & & & \\
\hline - Height, cm & 9.143 & 9.234 & 9.175 & & 8.840 & 8.889 & 8.952 & \\
\hline - Diameter, cm & 3.790 & 2.782 & 3.999 & & 2.699 & 2.716 & 2.813 & \\
\hline - Area, cm ${ }^{2}$ & 34.65 & 25.69 & 36.69 & & 23.86 & 24.14 & 25.18 & \\
\hline Distance in the erosian area, cm & 2.598 & 7.374 & 2.184 & & N/A & N/A & N/A & \\
\hline Difference final vs. original & & & & & & & & \\
\hline - Height, cm & 0.312 & 0.275 & 0.337 & $\mathbf{0 . 3 0 8}$ & 0.006 & 0.035 & 0.088 & $\mathbf{0 . 0 4 3 3}$ \\
\hline - Diameter, cm & 1.122 & 0.121 & 1.344 & $\mathbf{0 . 8 6 2}$ & 0.047 & 0.051 & 0.186 & $\mathbf{0 . 0 9 5}$ \\
\hline - Area, cm ${ }^{2}$ & 11.09 & 1.85 & 13.23 & $\mathbf{8 . 7 2}$ & 0.43 & 0.55 & 1.90 & $\mathbf{0 . 9 6}$ \\
\hline
\end{tabular}


The refractory bricks from the two domestic producers have no longer been used, instead refractory bricks from another domestic producer and imported bricks have been used during the amperage increase period and at present.

\section{Pot construction and operation}

The brickwork techniques were evaluated to determine whether they could be used on the test pots and on the remaining pots that were to operate with increased amperage. This entailed the following:

- Quality of the ramming paste and of the ramming operations;

- Other brickwork operations such as bricks setting, bus bar embedding;

- Assessing the brickwork materials recording system. In this respect, a database was created where all the materials used for the pot relining, together with related comments, are input.

Some pot autopsies revealed a bedding of the ramming paste layers, which indicated that the paste (hot paste produced in Alro) was over-rammed.

A small number of the analysed pots had holes over the cathode surface. These holes are sometimes produced by the areas which are overheated during the heating period.

The port start-up procedure was changed in order to have the pot brought to steady state as soon as possible.

The cathode blocks embedding procedure was changed in order to prevent cracking.

\section{Conclusions}

By hard team work and implementation of a number of innovative solutions, the following performances have been achieved:

- Increase lifetime of pots from 1440 to 2860 days;

- Decrease the consumption of direct current reactive electric power from $14.18 \mathrm{MWh} / \mathrm{Mt}$ to 13.28 MWh/Mt;

- The power efficiency increased from $92.3 \%$ to over $95.5 \%$;

- Following the pot design change, the electric power amperage was significantly increased such that the work amperage is currently of $120 \mathrm{kA}$.

The materials included in the cathode unit have been characterized in terms of mechanicalchemical properties. Everything in the cathodes affect thermal balance. Failure mode give us important clues in designing the technical specs of the materials.

Based on the laboratory test results, the technical specifications for the materials included in the cathode unit were revised and other, both domestic and imported materials were also tested and qualified.

After all this work coming together another conclusion was that the increasing lifespan of the pots needs to be well balanced between design, material quality, construction, start-up and operation. Special thanks to Mr. Richard Jeltsch, from whom we learned about pot autopsy, interpretations of results and other hints that help us improve our results continuously.

One major conclusion can be drawn from the amperage and production increase experience: by a selective use of retrofit technologies and by amperage increase, an over 50 year-old smelter can remain competitive on the market. 


\section{References}

[1] Dobra Gh., Stanescu C.et al. Cell Capacity Increase Program at Alro. Light Metals, 2005, $311-316$.

[2] Dobra Gh, Stanescu C. et al. Production Boost at ALRO. Light Metals, 2007.

[3] Cilianu M., Dobra Gh et al. Changes in Operating Practice and Vertical Integration Boosts ALRO Performance. ALRO paper, Krasnoyarsk 2015, 359-370.

[4] Dobra Gh., Cilianu M., Ciobanu G. et al. Technical measures for increasing the life of pots in ALRO Slatina. ALRO paper, Krasnoyarsk 2017, 301-312. 